\title{
日本人類遺伝学会第23回大会講演要旨 (1978)
}

\author{
Abstracts of Papers Communicated at the 23rd Annual Meeting \\ of the Japan Society of Human Genetics, 1978
}

\section{特別講演 I Review Lecture I}

\section{椿 忠雄 (新潟大・脳研)：遺伝と神経疾患. Tadao TSUBAKI (Brain Res. Inst. Ni- igata Univ.): Genetics and Neurological Diseases.}

疾患成立に和ける遗伝の役割性，1）単因子遗伝，2）染色体遺伝，3）多因子遗伝，4）外因に対す

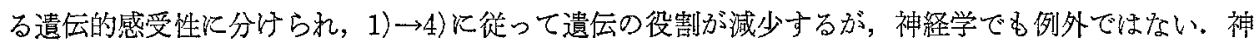
経疾患は一般に，外傷，感染，中毒，栄養欠乏，発作性異常，先天性代謝異常，免疫応答異常，脱檤

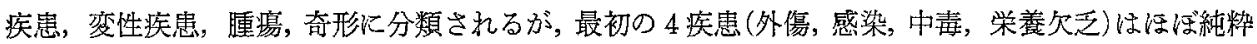

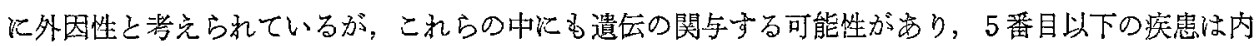
因性要たは内因と外因の相互作用炕よると分類される．新潟大神経内科外来患者 (1974 1976) 3, 344 例のうち，最初の 4 疾患は277例 $(8.3 \%)$ を占めるに過ぎず，5番目以下の疾患が91.7\%を占め，艺 の此率梳、。

一般厄単因子性遗伝をする疾患の頻度は低いと思われているが，単因子性遗伝性疾患を網羅した

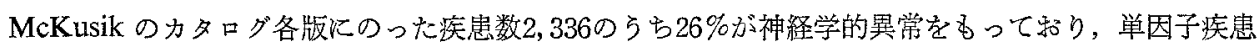
としての神経疾患の重要性が示される。

単因子性神経疾患の自験例上り，2，3 の知見を述べる.

1. 新潟県の脊盛小脳变性症の家系分布を調查したが，Friedreich 病と Marie 病は異なった分布 をしている.

2. 新潟県に存在する Marie 病の大家系恃, 従来の分類には含まれない橋・背䯣型と思われる.

3. Marinesco-Sjögren 症候群 9 例（7家系）を提示し，本症恪多面発現性の遺伝性症候群で， 4 主症候の表現にはかなりの動摇がある。

4. Ataxia telangiectasia の中核は免疫不全ではなく、より根本的な生化学的異常初そらくはDNA 代謝障害により発現したものであららとの推諭を䢞べた。

5. 本邦の遺伝性神経根性知覚性ニューロパチーは，国外の多くの例が優性遺伝で管ることと異な り, 多く注篻劣性である。

6. 家族性筋萎縮性側索硬化症で後索障害を有する型の臨床的特徵を示し, 古典型との相違を明ら かにした，後索障害型は孤発例がほとえどないのに対し，古典型は $2 \sim 3 \%$ のみに家族性発生をみ る. 後索障害型性不规則優性飞従亏遺伝性疾患と考えられる.

7. 琉球型筋萎縮晸を紹介した。德之島 23 例, 沖永良部島 8 例, 沖縄本島 1 例の特異な筋菱縮症で あり，患家の家系図より10数代の家系を追求することができた．遺公形式は学劣性であるが，有害な 劣性突然变異遗伝子により，何人かの保因者をつくり，その集団に大きな被害を半永久的に及ぼすこ とを示呇事例を示した.

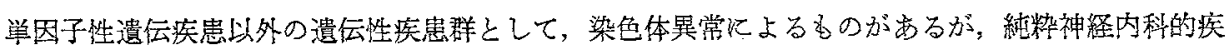


患で注重要なものが少ない、いっぽう多因子性遗伝の研究は最近，方法論的にも著しく発展して特り， 今後の神経疾患研究への発展が期待される. 多因子性であることが是われた神経疾患の数は多い.

ここで，福山型先天性筋ジストロフィ一症 (CMD) Kついて述べる.

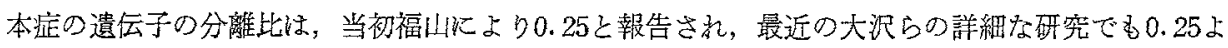

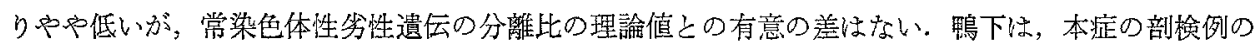
脳病理所見より胎内感染の可能性を示唆している. 文田らは12〜14歳（3例）の症例で，全例 IgM が異常高値を示したことを報告し，従来から胎内感染のスクリーニングテストに用いられている血清 $\operatorname{IgM}$ が三宅らの新生児例飞括いても高かったことを合せ考充て，胎览期よりなんらかの抗原刺激が続 いている可能性を推測した，胎内感染を执こしゃすい特殊な形筫の遗伝を考穴た鴨下の推論に対する 一つの根拠とも考光られる.

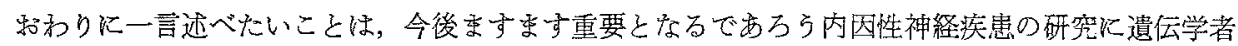
の心からの協力をのぞむるので岕る。

\section{特 別講 演 II Rewiew Lecture II}

Genes, Enzymes, and Hypoxia. William J. Schull (Professor of Medical Genetics, University of Texas Health Science Center at Houston)

Some ten million or more persons in South America reside at altitudes which would prompt some evidence of physiologic distress in most individuals indigenous to areas with sea level or near sea level partial oxygen pressures, yet the high altitude native seems to experience no difficulty. But has Andean man himself adapted? Has his genetic makeup been systematically altered as a consequence of the rigors of this environment? If so, how is one to demonstrate this fact?

This presentation will examine four lines of biochemical evidence pertinent of this issue, namely, (a) the frequency and fate of abnormal variants of hemoglobin, (b) the frequency and fate of deficiencies of glycolytic enzymes, (c) the frequency and fate of rare isozymic variants, and finally, (d) altitude related changes in the frequencies of the common alleles at polymorphic loci. 